\title{
A CONSTRUÇÃO DA MEMÓRIA E DA VERDADE NUMA PERSPECTIVA DE GÊNERO
}

\author{
Maria Amélia de Almeida Teles
}

CONSTRUCTION OF MEMORY AND TRUTH IN A GENDER PERSPECTIVE

\section{RESUMO}

O TEXTO DISCUTE A NECESSIDADE DE UMA CONSTRUÇÃO DA MEMÓRIA E DA VERDADE SOB UMA PERSPECTIVA DE GÊNERO ACERCA DA PARTICIPAÇÃO FEMININA NA RESISTÊNCIA CONTRA A DITADURA MILITAR BRASILEIRA (1964-1985), VISTO QUE ESTA OCORREU DE FORMA INTENSA E O TEMA AINDA HOJE NÃO É DEVIDAMENTE TRATADO

\section{PALAVRAS-CHAVE}

MEMÓRIA; VERDADE; GÊNERO; RESISTÊNCIA FEMININA; DITADURA MILITAR.

\section{ABSTRACT}

THE PAPER DISCUSSES THE NECESSITY OF A CONSTRUCTION OF MEMORY AND TRUTH FROM A GENDER PERSPECTIVE ON WOMEN'S PARTICIPATION IN THE RESISTANCE AGAINST THE BRAZILIAN MILITARY DICTATORSHIP (1964-1985), AS THIS OCCURRED IN AN INTENSE WAY AND THE ISSUE IS STILL NOT PROPERLY TREATED.

\section{KEYWORDS}

MEMORY; TRUE; GENDER; FEMALE RESISTANCE; MILITARY DICTATORSHIP.

Espancaram-me no rosto até eu ficar desfigurada. [...] O "Márcio" invadia minha cela para "examinar" meu ânus e verificar se o "Camarão" havia praticado sodomia comigo. Esse mesmo "Márcio" obrigou-me a segurar seu pênis, enquanto se contorcia obscenamente. Durante esse período fui estuprada duas vezes pelo "Camarão" e era obrigada a limpar a cozinha completamente nua, ouvindo gracejos e obscenidades, os mais grosseiros [...]

(Inês Etienne Romeu ${ }^{1}$ ) 


\section{INTRODUÇÃO}

Ao tratar do tema "verdade e gênero", temos que referenciar as mulheres na luta contra a ditadura militar (1964-1985). E isso me traz à memória a militante Inês Etienne Romeu, que faleceu recentemente, em 27 de abril de 2015, com 73 anos de idade. Ela foi presa política, sequestrada por um dos mais "temidos" torturadores da época, Sérgio Paranhos Fleury, delegado do Dops-SP e chefe do "Esquadrão da Morte". ${ }^{2}$ De imediato, foi transferida para o Rio de Janeiro, onde passou pelo DOI-Codi ${ }^{3}$ e, em seguida, foi entregue ao pessoal do Centro de Informações do Exército (CIE), que a levou para um centro clandestino da repressão, que mais tarde, graças às suas denúncias, ficou conhecido como "Casa da Morte", localizado em Petrópolis (RJ). Aliás, ela é a única sobrevivente desse centro clandestino que denunciou publicamente. Um dos principais integrantes do CIE, o coronel do Exército Paulo Malhães (1937-2014), conforme seu próprio depoimento à Comissão Nacional da Verdade e à Comissão da Verdade do Estado do Rio de Janeiro, era um dos responsáveis pela criação e manutenção da "Casa da Morte", montada para torturar militantes políticos de oposição a fim de transformá-los em agentes de “informação" ou "agentes infiltrados" e, assim, desmantelar as organizações da esquerda. As informações que vinham de dentro do próprio movimento subsidiaram os agentes e todo o aparato repressivo na intensificação da perseguição e extermínio dessas organizações. Os agentes públicos, como o coronel Paulo Malhães, que também usava o codinome Dr. Pablo, obrigavam os militantes a trabalhar para eles - caso resistissem, eram mortos.

Inês sofreu pressão para se transformar em "espiã" da esquerda. Depois de muito torturada, tentou suicídio, e quando teve finalmente sua prisão "oficializada", com muita coragem e dignidade, ainda sob o total controle dos repressores, denunciou os crimes bárbaros a que foi submetida. Aqui faço uma pequena homenagem a ela, com um trecho do texto que escrevi por ocasião de sua morte em Niterói (RJ):

O aparato repressivo misógino da ditadura militar não suportava a inteligência, a ousadia e capacidade estrategista de Inês. Ela fugia totalmente ao estereótipo da submissão, da subalternidade e da falta de iniciativa. Ela foi a única sobrevivente da Casa da Morte (um dos principais centros clandestinos, localizado em Petrópolis-RJ). Os torturadores a estupraram, a espancaram, a humilharam, a violentaram de todas as maneiras. Mas ela manteve íntegra sua dignidade e enfrentou o terror e o medo para denunciá-los. Graças a sua capacidade de observar e registrar, ela guardou em sua memória os detalhes do lugar onde estava e assim denunciou a "Casa de Petrópolis". Suas denúncias, feitas por escrito por ela mesma, ainda em 1971 e 1979, o que significa em plena ditadura, são valorosas ainda nos dias de hoje, no pós Comissão da Verdade. Com sua atitude 
ousada, ela antecipou a Comissão da Verdade. Seu nome deve se inscrever em espaço relevante na história brasileira. Ela se foi. Seu legado fica no memorial dos que defenderam a democracia e sua consolidação. O seu legado maior sempre foi e será a verdade histórica. Oxalá, o Estado brasileiro venha, de fato, investigar os crimes de lesa-humanidade, como os estupros, os desaparecimentos forçados cometidos pela ditadura militar, testemunhados por Inês Etienne. Esta seria a maior homenagem a esta mulher que dedicou sua vida à defesa da justiça. (TELES, 2015).

Outras mulheres militantes políticas passaram por situações semelhantes, ou muito difíceis, tanto na clandestinidade como nos cárceres da ditadura. No entanto, são pouco lembradas e reconhecidas. Quando pensei, juntamente com outras ex-presas políticas, em tratar do tema "verdade e gênero", encontrei resistência por parte de integrantes da Comissão da Verdade, profissionais e ativistas que lidavam com as questões relativas à verdade. Alegavam que tanto homens como mulheres foram igualmente torturados, assassinados e desaparecidos. Por que dar destaque às mulheres? A minha resposta é que a tortura é imensurável tanto para homens como para mulheres. A tortura dilacera a dignidade humana de ambos os sexos. Mas as mulheres, por serem historicamente discriminadas, sofrem efeitos específicos.

A expressão gênero usada aqui nos remete "[...] a relações sociais de poder, especialmente ao modo como diferenças corporais entre homens e mulheres são percebidas socialmente e como podem ser convertidas em desigualdade. [...]" (FACCHINI, 2015).

Portanto, gênero é uma estrutura social que constrói relações desiguais e legitima a desigualdade na participação política, social, econômica e cultural entre mulheres e homens, independentemente da classe social, raça/etnia, orientação sexual, faixa etária. Daí a necessidade de investigar os crimes da ditadura militar sob a perspectiva de gênero, porque tais crimes, embora sejam graves violações de direitos humanos de homens e mulheres, são praticados de forma distinta quando se trata de violações de direitos humanos das mulheres. A ditadura aliou o ódio aos oposicionistas ao ódio às mulheres. As condições específicas das mulheres, como a gravidez, a maternidade, o parto, o aleitamento materno, o abortamento, a menstruação e até mesmo o fato de serem simplesmente mulheres, foram usados, pela repressão política, como mais um recurso para torturar e violentar as mulheres. Ou seja, os agentes do Estado ditatorial utilizaram da condição feminina para acirrar todo o processo de repressão contra a população, inclusive para executar os sequestros, as tor turas e os assassinatos. Conspurcaram a dignidade das mulheres que participaram da luta contra a ditadura e isso trouxe um legado à história política de nosso país que não pode ser ignorado, como tem sido até os dias de hoje, sob pena de não superá-lo. A investigação histórica da luta de oposição à ditadura na perspectiva de gênero deve 
significar a inclusão das mulheres na medida real de sua participação, como agiram as organizações do aparato repressivo da ditadura contra elas, mas também trazer à tona a atuação das militantes. Além disso, hoje, temos novas informações sobre a atuação de mulheres como agentes policiais do aparato repressivo, como o do DOI-Codi-SP. A publicação de algumas investigações nos revela que algumas dessas mulheres tiveram uma atuação como torturadoras ou no apoio logístico para as práticas da tortura nesse órgão.

Pretendo, neste texto, enfatizar a atuação dos órgãos públicos da repressão política em relação às mulheres militantes e também mencionar a repressão praticada por agentes femininas da polícia militar, ainda que haja pouco material sobre o assunto. Não poderei deixar de comentar a atuação machista das organizações de esquerda que impediram uma maior participação das mulheres na luta contra a ditadura. Por último, quero fazer um registro bem breve da solidariedade anônima de mulheres que nos garantiram a vida e a sobrevivência.

\section{O "INIMIGO INTERNO" TEM SEXO?}

Para minhas companheiras que eu nunca mais verei. Tiveram suas vidas ceifadas sem sequer chegar aos 30 anos de idade. As relações de gênero assim como as relações étnico-raciais tiveram influência em nosso passado e como...

(Maria Amélia de Almeida Teles)

A ditadura militar brasileira teve como alvo principal, com base teórica e política na doutrina de segurança nacional, eliminar e/ou destruir o potencial criativo e mobilizador do inimigo interno, conforme denominação adotada pelos estrategistas militares da época. Esse inimigo interno poderia ser qualquer pessoa ou grupo de pessoas que se encontrassem no meio do povo. Inverteu-se assim o princípio do Estado de direito, e todos passaram a ser suspeitos até provarem o contrário.

A repressão política não poupou mulheres e homens que procuraram resistir e criar novas formas de organização e luta.

Sem dúvida, as mulheres foram o segmento da população que mais apresentou mudanças nas suas relações com o trabalho, a família, os homens e também no campo da política. Já que a política era assunto proibido para homens e mulheres. As mudanças políticas, econômicas e sociais, ocorreram, tão bruscamente, em decorrência da implantação da ditadura. Ao negar e proibir a realização da reforma agrária, ao facilitar a entrada do capital estrangeiro, e principalmente das multinacionais, a política ditatorial expulsou a população camponesa da terra causando o deslocamento forçado da população rural para as áreas urbanas. Tal acontecimento afetou e alterou o comportamento social, em especial das mulheres, numa perspectiva de tratar de forma 
mais abrangente as questões do cotidiano privado e público. Ocorreram outras mudanças pelo mundo que tiveram efeito direto na vida das mulheres. Nos anos 1960, havia sido descoberta a pílula anticoncepcional, que trouxe a possibilidade de se ter relações sexuais sem medo de engravidar. Outro fator que repercutiu na vida das brasileiras foi a ascensão dos movimentos feministas na Europa e nos Estados Unidos, que questionavam o patriarcado e colocavam em xeque o comportamento machista e sexista. Na medida que isso ocorria, impulsionou-se a chamada revolução sexual de 1968, na qual os jovens estudantes, inclusive as mulheres, se rebelaram em diversos países em busca de liberdades.

[...] escrever em jornal, sair de casa, fazer teatro, fumar, eu comecei a fumar aos 16 anos [...] e o fato de que eu defendia o amor livre. Bom, também fui a primeira moça de Vitória a botar biquíni. Hoje é que eu avalio como isso era radical e continua sendo. (GIANORDOLI-

-NASCIMENTO et al., 2012, p. 77).

No Brasil, uma parcela de mulheres entrou nos movimentos de luta política contra a ditadura, inclusive na luta armada. Muitas foram viver clandestinas. Precisavam tornar-se invisíveis a cada momento de mais intensa perseguição. Outras foram viver nas periferias das grandes cidades, na área rural e até na selva amazônica, onde ocorreu o movimento guerrilheiro do Araguaia. A repressão implacável as obrigava a mudar de lugar, e em cada lugar precisavam de uma nova identidade. Nas diversas formas de luta adotadas pela esquerda, as pessoas militantes tiveram de enfrentar o risco de sequestro, tortura, morte e desaparecimento forçado.

Mesmo assim as mulheres se comprometeram com as mais diversas organizações da esquerda e participaram de todas as atividades da luta. Enfrentaram a misoginia da ditadura e também a da esquerda.

Renata estava ali (no partido) para lutar por um lugar na organização; tinha total certeza de que poderia ascender no partido e contribuir de forma mais eficiente. Passou a questionar sua posição e a discriminação que sofria como mulher, porque sabia que tinha condição de se destacar, de subir na hierarquia do partido, mas isso nunca foi permitido. Nesse momento já tinha consciência de que sua luta não era só pela liberdade, mas por um lugar social para a mulher. "Mas esta discussão não tinha o menor espaço no partido.” [...] (GIANORDOLI-NASCIMENTO et al., 2012, p. 200).

As organizações políticas de esquerda relutaram em incorporar as mulheres militantes de acordo com o protagonismo que elas já vinham obtendo na vida social e familiar. 
O que significava que as mulheres já começavam a agir de uma forma mais autônoma, com capacidade de decisão, com opiniões próprias e tomando mais iniciativas. Talvez as direções da esquerda acreditassem que, por ser tão dura a repressão, as mulheres não conseguiriam enfrentar o inimigo truculento. Talvez quisessem poupar as mulheres, como se isso fosse possível. Mas talvez o fator determinante tenha sido a falta de compreensão da necessidade da participação das mulheres para que houvesse uma mudança histórica da sociedade. Não acreditavam na força política das mulheres. De fato, as organizações de esquerda ainda eram bastante dogmáticas e conservadoras e tinham dificuldade de compreender a mudança de comportamento social das mulheres e que elas queriam ficar à frente das lutas e tinham o direito de protagonizá-las.

[...] Daí a história de discutir todos os padrões, virgindade, tal. Então eu fiz uma guerra tripla, minha guerra era contra o governo, era contra a religião, os princípios e todo o tradicionalismo... e uma guerra contra o papel da mulher. Então eu sabia que eu tava numa guerra mais ampla. [...] (GIANORDOLI-NASCIMENTO et al., 2012, p. 209).

Mas a ditadura, à medida que a oposição se mobilizava com ações políticas e armadas, percebeu a força das mulheres na luta e começou a persegui-las com todo o rigor repressivo. Na luta contra a ditadura, armada ou não, participaram mulheres brancas, negras, orientais (japonesas). Para a ditadura o inimigo tinha sexo, raça/etnia e classe social, e as mulheres só eram comparáveis aos gays, nas palavras de um dos matadores e torturadores da época, o alto oficial do Exército já citado acima coronel Paulo Malhães:

[...] Guerrilheiras mulheres, ele disse que via como se fossem homens. Mas "eu tinha verdadeiro pavor de interrogar as mulheres e, vamos dizer, gays, para não usar a palavra que se usava naquele tempo" [...]

[...] Isso porque mulheres ou homossexuais, segundo o coronel, preferiam morrer a revelar os nomes dos amantes ou maridos. Já os homens falariam depois de duas ou três horas. "Você 'ganhar' uma mulher é uma coisa, assim, de outro mundo", disse, sem precisar a que método de interrogatório se referia. [...] (CARNEIRO, 2014).

Como militantes de esquerda, as mulheres sofreram sequestros e prisões irregulares, foram submetidas a torturas diversas. Houve aquelas que foram torturadas até a morte, algumas tiveram seus corpos sepultados por parentes, outras têm seus corpos insepultos até os dias de hoje.

Com tantas dificuldades, causa surpresa saber que a participação das mulheres na militância foi expressiva. 
Na guerrilha rural do Araguaia (localizada no sul do Pará), havia 17\% de mulheres guerrilheiras (COMISSÃO DE FAMILIARES DE MORTOS E DESAPARECIDOS POLÍTICOS, 2009). O projeto Brasil Nunca Mais apresentou uma pesquisa sobre os processos da justiça militar e chegou a analisar a situação processual de cerca de 7.367 militantes. Desse total, 12\% são mulheres (TELES, 1993). De acordo com estudos do Estado-Maior do Exército, em 1970, de um total de quinhentos militantes aprisionados em quartéis do Exército 20\% eram mulheres, sendo que no Rio de Janeiro essa cifra chegou a 26\% (GIANORDOLI-NASCIMENTO et al., 2012, p. 44). No Dossiê Ditadura, no qual são apresentados 436 casos de assassinatos ou desaparecimentos forçados, 51 deles são de mulheres, o que representa 11\% dos casos.

Esses índices são ainda mais significativos se comparados aos índices de participação das mulheres na política nos dias atuais. Hoje uma mulher ocupa o cargo de presidenta da República, Dilma Roussef, reeleita pelo voto popular em 2014. (É bom lembrar que Dilma foi presa política, participou da luta armada, foi torturada e condenada pela Lei de Segurança Nacional.) Mas as mulheres continuam sub-representadas na política. Nas eleições de 2014, foram eleitas 51 mulheres para a Câmara Federal, o que significa 9,9\%. No Senado, com as últimas eleições, passaram a ser 13,6\% (CRESCE..., 2014).

\section{Mulheres guerrilheiras}

Nossa geração teve pouco tempo, começou do fim

Mas foi bela nossa procura

Ah! Moça, como foi bela a nossa procura,

Mesmo com tanta ilusão perdida, quebrada,

Mesmo com tanto caco de sonho

Onde até hoje a gente se corta!

(Alex Alverga, 1978)

No que se refere às mulheres assassinadas/desaparecidas, mesmo com o funcionamento da Comissão Nacional da Verdade, criada pela Lei n. 12.528/2012, cujo período de vigência se deu de 16 de maio de 2012 a 10 de dezembro de 2014, ocorreram pouquíssimos avanços nas investigações dos casos. Houve uma negação de responsabilidade por parte das Forças Armadas e do Ministério das Relações Exteriores, dois ministérios que concentram informações sobre o período, que se recusaram a dar informações, principalmente sobre os desaparecimentos e/ou assassinatos. 
É fundamental ressaltar a grande dificuldade de acesso aos arquivos públicos, mais notadamente os da ditadura: instituições como as Forças Armadas e o Ministério das Relações Exteriores, fundamentais para a cadeia de repressão e o sistema de vigilância, continuam a negar o acesso a certos documentos do período, ainda desconhecidos, e ainda não fizeram a autocrítica necessária para a vida democrática. (COMISSÃO DA VERDADE DO ESTADO DE SÃO PAULO)

Com todo esse cerceamento às informações houve denúncias nas Comissões da Verdade que merecem um aprofundamento das investigações e devem ser judicializadas sob pena de o Estado brasileiro mais uma vez legitimar as graves violações de direitos humanos, perpetuando assim a violência, a tortura, os assassinatos e os desaparecimentos forçados por parte de agentes do Estado.

Maria Augusta Thomaz era militante do Movimento de Libertação Popular (Molipo), um grupo político revolucionário de esquerda, da luta armada, o que a fez se tornar uma guerrilheira. Nascida em 14 de novembro de 1947, na cidade de Leme, São Paulo, é desaparecida política desde 17 de maio de 1973. Ela, junto com seu companheiro Márcio Beck Machado (1943-1973), foram mortos por agentes do DOI-Codi-SP e do CIE em uma fazenda situada entre as cidades de Rio Verde e Jataí, na época no estado de Goiás. Seus corpos jamais foram entregues a seus familiares para que fossem sepultados - "A morte de Maria Augusta e Márcio teria sido comentada nos corredores do DOI-Codi paulista, segundo o depoimento de vários presos políticos, detidos naquela época" (COMISSÃO DE FAMILIARES DE MORTOS E DESAPARECIDOS POLÍTICOS, 2009, p. 438).

Maria Augusta, em sua militância política, junto com oito companheiros (todos homens, ela era a única mulher), sequestrou um avião Boeing, da Varig, durante o trajeto Buenos Aires-Santiago, desviando-o para Cuba. Todos foram para lá para fazer treinamento militar. Mas Maria Augusta encontrou oposição dos próprios companheiros quanto à sua participação no treinamento.

Ela participou do treinamento em Cuba, e é importante dizer isso, contra a vontade dos companheiros. Ela me contou isso. Cuba tem um viés machista muito forte. E ela me contava que, quando chegou em Cuba, o treinamento era ir para uma região distante, região de mata, para fazer o treinamento ali e vivendo a mata [...], enfim, todas as coisas que você pode imaginar que dizem respeito a sua sobrevivência na mata. Porque o objetivo da guerrilha no Brasil era se deslocar para o campo. E quando se discutiu quem ia, havia uma visão de não ir mulheres, porque mulheres menstruam, têm problemas, têm certa dificuldade, etc. e etc. A Maria Augusta não aceitou isso e ela foi junto com os demais companheiros para 
o treinamento e ela falava com muito orgulho disso. Havia uma graduação entre todos os companheiros que faziam o treinamento. E a Maria Augusta ficou na segunda posição... ${ }^{4}$

Maria Augusta foi um exemplo de uma jovem estudante que rompeu com os tabus, inclusive da esquerda, que considerava as mulheres incapazes de assumir uma luta política extrema.

Hoje, o nome da Maria Augusta Thomaz faz parte da lista dos desaparecidos políticos que nunca tiveram um sepultamento digno.

Sonia Maria Lopes de Moraes Angel Jones (1946-1973), também guerrilheira, era militante da Ação Libertadora Nacional (ALN) e foi sequestrada junto com seu companheiro (também da ALN), Antônio Carlos Bicalho Lana, na cidade de São Vicente, litoral paulista, e levados para o DOI-Codi (SP) (BRASIL, 2014b, p. 1430). O pai dela, professor Moraes, que havia sido coronel do Exército, conseguiu levantar muitas informações a respeito do sequestro, da tortura e do assassinato da filha. O então coronel Adyr Fiuza (comandante do DOI-Codi do Rio de Janeiro) teria enviado para a família o cassetete com o qual ela teria sido torturada e estuprada, o que lhe teria causado hemorragia interna, levando-a à morte. Antes de morrer, seus seios teriam sido decepados. Segundo outra versão, o depoimento de uma testemunha (uma mulher agente da repressão), Sonia se encontrava no DOI-Codi de São Paulo, sob o comando do então major Carlos Alberto Brilhante Ustra, e de lá ela e seu companheiro foram transferidos para o sítio, centro clandestino da repressão, onde teria sido submetida a brutais torturas - a introdução de um camundongo em sua vagina teria causado uma hemorragia interna. ${ }^{5}$ Isso teria sido feito pelo torturador Lourival Gaeta, ${ }^{6}$ com a conivência dessa mulher policial, que também participou da ação e não autorizou que seu depoimento à Comissão Nacional da Verdade nem sua identidade fossem tornados públicos. Sonia foi torturada, estuprada, assassinada e teve seu corpo ocultado por décadas.

O relatório da Comissão Nacional da Verdade contém a denúncia de que o torturador Lourival Gaeta utilizava animais na prática de tortura - cachorros, ratos, jacarés, cobras, baratas, eram lançados contra as pessoas torturadas ou introduzidos em alguma parte do seu corpo.

[...] Especificamente em relação aos camundongos, o torturador, Lourival

Gaeta, que atuou no DOI durante a década de 1970, em São Paulo, explicava sua destrutividade uma vez introduzidos nos corpos das suas vítimas com o argumento de que este animal não sabe andar para trás. (BRASIL, 2014a, p. 373, 374).

Ana Rosa Kucinsky Silva (1942-1974) e seu companheiro, Wilson Silva (19421974), encontram-se desaparecidos desde 22 de abril de 1974. Ana Rosa era professora 
na Escola de Química da USP. Saiu do trabalho para encontrar-se com seu companheiro, em local próximo à Praça da República, no centro de São Paulo, e nunca mais foi vista. O delegado de polícia Cláudio Guerra, que era vinculado ao SNI e trabalhou junto ao CIE para matar e ocultar os corpos, declarou, no livro Memórias de uma guerra suja, que na época levou doze corpos para serem queimados no forno da Usina Cambayba, em Campos de Goytacazes (RJ) (GUERRA, 2012). Entre os corpos, estavam os de Ana Rosa e Wilson. O corpo de Ana Rosa tinha "marcas de mordidas, talvez por ter sido assaltada sexualmente" e o de Wilson "não tinha unhas na mão direita” (FARIA, 2012).

[...] entre os agentes da repressão do período da ditadura que confirmaram a prática das torturas está o ex-delegado Cláudio Guerra, do Dops do Espírito Santo e atual pastor evangélico. Guerra, membro de uma das equipes do coronel Freddie Perdigão (um dos integrantes do CIE), mencionou, em 23 de julho de 2014, que este último tinha dois grupos de trabalho distintos e secretos: um de tortura e interrogatório e outro de execução (do qual Guerra fazia parte). Fez referência específica ao caso de Ana Rosa Kucinski Silva, militante da ALN, que, conforme seu relato, teria sido torturada brutalmente no centro clandestino de Petrópolis conhecido por Casa da Morte, inclusive sexualmente: "Ela estava em Petrópolis e foi muito torturada. Ela estava visivelmente violentada. Com os órgãos genitais cheios de sangue e a roupa cheia de sangue". (BRASIL, 2014a, p. 344).

As informações dos detalhes e requintes das mortes nos chegam pelos próprios agentes que as executaram ou por agentes que estavam junto com os executores. Foram poucos os agentes que falaram. Mas é constante em suas falas o fato de que quase sempre as mulheres foram estupradas antes de serem mortas.

Mulheres guerrilheiras, mesmo capturadas, sem armas e sem condições de resistir, foram executadas, pois o Exército e as demais forças armadas se sentiriam desmoralizados se elas permanecessem vivas. Talvez o caso mais emblemático seja o de Dinalva Oliveira Teixeira (1945-1974), guerrilheira do Araguaia, famosa naquelas áreas da guerrilha e conhecida por Dina.

Ex-guerrilheiros presos na época comentaram que (ela) era temida pelos militares. Tornou-se uma figura lendária por ser exímia atiradora.

[...] Em matéria do Jornal do Brasil, de 12 de abril de 1992, o coronel da reserva Sebastião Rodrigues de Moura, o Curió, um dos oficiais do CIE enviado para reprimir a guerrilha, destaca a coragem das guerrilheiras do $\mathrm{PCdoB}$, conta que sua audácia era temida pelos soldados e que Dinalva 
foi a última guerrilheira a tombar, após uma perseguição que se estendeu por mais de quatro meses.

Depoimento do coronel da Aeronáutica Pedro Cabral à revista Veja, de 13 de outubro de 1993, e à Comissão de Representação Externa da Câmara Federal, faz referência a uma guerrilheira grávida que teria sido morta. Há também comentários de moradores da região que fazem referência à gravidez em estado avançado de Dina. [...]

De acordo com Elio Gaspari no livro “A Ditadura Escancarada”, [...] a mitológica Dina foi assassinada grávida. Ela estava sob o controle do major Curió. (COMISSÃO DE FAMILIARES DE MORTOS E DESAPARECIDOS POLÍTICOS, 2009, p. 582-583).

Dinalva Teixeira foi a única guerrilheira da luta contra a ditadura militar que chegou a ocupar o cargo de vice-comandanta da guerrilha do Araguaia. O Exército e as demais forças armadas investiram impetuosamente contra ela, pois ficariam muito desmoralizados se a deixassem viva na selva.

O nome de Dinalva era um dos poucos não riscados na folha pregada na parede da Casa Azul. ${ }^{7}$ Era a "peça" que faltava para o Exército considerar extinta a guerrilha. Com a mulher que virava borboleta, pomba e cupim livre na mata, a vitória da repressão jamais seria assimilada pelos caboclos nos barrancos dos rios, garimpos e povoados, acreditavam os militares. (NOSSA, 2012, p. 209).

\section{Mulheres torturadoras?!}

O passado está aqui com seus gemidos... (Mario Benedetti ${ }^{8}$ )

Por décadas, acreditamos que as mulheres agentes da repressão não atuavam diretamente na prática da tortura dentro do DOI-Codi. Pensávamos que elas faziam parte do esquema de monitoramento e perseguição aos militantes de esquerda. Geralmente, em suas ações, simulavam um “casal de namorados” ou então faziam parte das "encenações" de tiroteios, que eram constantes.

A tenente Neuza, uma das policiais que atuou no DOI-Codi de São Paulo, esclareceu o que a motivava para realizar seu trabalho naquele lugar conhecido também “O Inferno" ou "Casa dos Horrores": "Era uma guerra e eu estava defendendo a minha pátria” (GODOY, 2014, p. 150). 
Nela não se vê nenhum sinal de arrependimento, "[...] embora acredite que sua corporação tenha vergonha do que ela e seus colegas fizeram” (GODOY, 2014, p. 150).

Criado em 1955, na Guarda Civil, o Corpo de Policiamento Especial Feminino, contava com treze mulheres policiais no estado de São Paulo. Na década de 1970, com o nome de Quadro Especial de Policiamento Feminino, já eram oitenta as policiais femininas, e algumas delas foram trabalhar na Operação Bandeirante (Oban), que mais tarde teve o nome de DOI-Codi.

O jornalista Marcelo Godoy descreve a participação das policiais mulheres no DOI a partir de entrevistas feitas com elas. Elas disseram que nenhuma fazia parte das equipes de busca ou de interrogatórios. Atuavam na vigilância, seguiam os militantes perseguidos e se responsabilizavam por fazer fotografias dos suspeitos: "Quem iria desconfiar de uma mulher?”.

Os militares logo se deram conta da importância do trabalho delas. O então coronel Audir Santos Maciel (comandante do DOI-Codi-SP de 1974 a 1976) disse: "No telefone fazia um levantamento completo de uma ocorrência, o que economiza horas e horas de "paquera'” (GODOY, 2014, p. 148).

A tenente Neuza se refere assim ao seu trabalho: "Aí eu fui pro meu 'Açougue' [DOI] e aí passaram a acreditar que a mulher também tinha capacidade" (GODOY, 2014, p. 148). Ela participou de "prisão", de emboscadas e de "tiroteios" seguidos de mortes. É importante destacar que as notícias de tiroteios eram falsas (GODOY, 2014, p. 21). Aliás, a própria tenente esclareceu que eram feitas "encenações" para simular os "tiroteios". As mortes ocorriam devido às intensas e brutais torturas a que eram submetidos os militantes políticos. Os agentes responsáveis pelas torturas até a morte, em muitos casos, não têm seus nomes conhecidos pelos próprios presos políticos da época - a não ser quando os próprios agentes assumem seus feitos e levam a público os assassinatos cometidos, o que tem sido muito raro. Dos poucos agentes que falaram, alguns acabaram sendo mortos pelos próprios colegas.

A tenente Neuza assumiu que participou de episódios que resultaram em mortes. Um deles, chamado "a emboscada no restaurante Varella", ocorrido no bairro da Mooca, em 14 de junho de 1972, levou à morte três militantes da ALN: Ana Maria Nacinovic Corrêa (1947-1972), Iuri Xavier Pereira (1948-1972) e Marcos Antonio Nonato (1953-1972). A tenente foi condecorada pelo general Humberto de Souza Mello, comandante do $2^{\circ}$ Exército na época (1973). Mas não foi só desse que a tenente participou. Segundo seu próprio depoimento, ela participou de outra emboscada, dessa vez no bairro da Penha, em 15 de março de 1973, episódio que ficou conhecido como "emboscada da rua Caquito" e que causou mais três mortes de militantes políticos da ALN: Arnaldo Cardoso Rocha (1949-1973), Francisco Emanoel Penteado (1952-1973) e Francisco Seiko Okama (1947-1973). A versão do aparato repressivo sobre as mortes é a de que todos esses militantes foram "mortos em tiroteio". O que ocorria de fato é que eram capturados com vida, torturados e depois assassinados. 
Foi assim que a tenente esclareceu:

Tinha muita gente que era presa e o jornal, você sabe, tinha censura, era complicado. Então falavam que o cara havia morrido em tiroteio. Levavam uma pessoa parecida, balas de festim e "matavam” um dos nossos lá. Mas o cara [o preso] ainda estava vivo. Aí ia ver se ele entregava alguma coisa, mas o cara não queria falar nada e aí viajava (era assassinado) [...]. (GODOY, 2014, p. 24).

Ela teria participado de operações militares que tiveram como resultado a morte de pelo menos dez militantes políticos e o desaparecimento de três: Hiram de Lima Pereira (1913-1975) e José Montenegro de Lima (1943-1975), do Partido Comunista Brasileiro (PCB), e Paulo Stuart Wright (1933-1973), da Ação Popular Marxista Leninista (APML).

Esta policial foi uma das sequestradoras dos meus filhos de 5 e 4 anos de idade, Janaina e Edson Teles, juntamente com minha irmã que se encontrava grávida de 8 meses, Criméia de Almeida. Eu tinha visto no DOI-Codi-SP, no final de 1972, vésperas do ano novo, esta policial que circulava na parte superior daquele prédio, juntamente com o Comandante Carlos Alberto Brilhante Ustra. Foi ela que entregou meus filhos ao Ustra, que os levou até a sala onde eu estava na "cadeira de dragão". 9 Pude reconhecê-la por foto quando foi lançado o livro Casa da vovó. Na foto, ela está sendo condecorada com "a medalha do Pacificador" pelo Comandante do $2^{\circ}$ Exército, general Humberto de Souza Mello. ${ }^{10}$

Ao que se sabe, foi em São Paulo que teve início o trabalho repressivo com a atuação de policiais femininas. O DOI-Codi do Rio de Janeiro requisitou da polícia paulista algumas mulheres policiais para atuarem no estado. Segundo a tenente Neuza, foram para o Rio cinco paulistas, que participaram de "todo o período duro da guerra".

\section{AÇões de SOlidariedade}

A sobrevivência de muitos militantes se deveu principalmente ao apoio e à solidariedade por parte de pessoas, na grande maioria, anônimas, que, individualmente ou em grupo, ofereciam contribuições em dinheiro, alimentos, medicamentos, roupas, moradia e emprego.

Houve muitas mulheres solidárias às pessoas que saíam das prisões sem saber exatamente como recomeçar a vida, uma vez que, de um modo geral, tinham perdido tudo ou quase tudo.

Essas pessoas solidárias passavam a ser perseguidas também, pois o fato de serem solidárias incomodava os repressores. Era um tempo em que a solidariedade era proibida. 
Aqui quero lembrar da Ilo (era assim que ela era chamada), uma alemã judia que dirigia um centro de orientação para pessoas excepcionais (na época, pessoas com deficiência mental eram chamadas de “excepcionais”). Quando saí da cadeia, fui procurar emprego, o que não era nada fácil. Todos os dias eu saía de casa e as portas do mercado de trabalho se fechavam para mim quando queriam saber por que passei um tempo sem trabalhar. Como eu não podia explicar a razão, vinha a negativa do emprego. Até que um dia alguém me falou: "Por que você não procura a Ilo?".

Cheguei até ela, que me pediu que fizesse uma prova, e fui selecionada. Comecei a trabalhar e fiquei muito feliz quando recebi meu primeiro salário. Dias depois, a Ilo me chamou no seu escritório e perguntou de cara: "Você foi presa política? Você está sendo processada pela Lei de Segurança Nacional?”.

Pensei logo: "Ela descobriu quem eu sou e vai me mandar embora. Que pena estava tão bom trabalhando aqui”. Respondi que fui presa política e estava sendo processada pela Lei de Segurança Nacional.

Então a Ilo me falou: "Eu queria saber porque veio aqui um cara do Dops e me disse que eu estava contratando uma funcionária que era terrorista. Como assim?, perguntei a ele. Aí ele disse que você tinha recém-saído da prisão mas continuava respondendo processo pelos crimes de subversão, etc. Pois sabe o que eu disse a ele? Aqui ela é uma funcionária com capacidade para exercer as funções que vêm exercendo. Eu preciso do trabalho dela. Ele ainda me deu a seguinte ordem: 'A senhora tem que mandá-la embora. Ela tem que ser demitida'. E eu respondi: 'Ela não será demitida. O senhor entendeu bem? Ela faz o trabalho que lhe cabe aqui e o senhor que cuide do seu'”.

O alívio e a alegria me invadiram o peito e a alma. Eu a abracei chorando, e entre nós nasceu um afeto grande. Ficamos amigas para sempre. Ela, na ocasião, me contou que havia fugido da Alemanha nazista pois era perseguida por ser judia e sabia muito bem o que é ser perseguida por uma ditadura. Ilo morreu em 2008, aos 81 anos de idade. Pouca gente sabe dessa história. Pela primeira vez, conto por escrito esse episódio.

Quanta solidariedade silenciada e anônima salvou a vida e a dignidade de tanta gente perseguida.

\section{CONCLUSÕES}

[...] necessitamos muito tempo para aprender a linguagem cotidiana da liberdade [...]. (AMERY, 2006).

A sociedade e o Estado brasileiros precisam escutar e falar sobre a violência contra as mulheres praticada pelos agentes públicos durante a vigência da ditadura militar 
(1964-1985). Esses fatos, muitos deles só revelados no calor dos debates criados recentemente pelas Comissões da Verdade, deveriam ser de conhecimento do público há muito tempo. Os poderes do Estado, devidamente habilitados para apurar e investigar tais denúncias, devem tomar iniciativas capazes de dignificar as mulheres e as demais vítimas. Deveriam mostrar de forma cabal e concreta que o país não suporta, nem deve suportar, a prática de torturas. O país deve repudiar também as práticas de torturas sexuais, levadas a cabo por agentes do Estado, respaldados por estratégicas e políticas de extermínio dos grupos opositores.

É necessário dar destaque e reconhecimento às mulheres que enfrentaram a ditadura, principalmente àquelas que tiveram suas vidas ceifadas na defesa de um ideal de liberdade e igualdade de direitos, condições e oportunidades para a construção de uma sociedade justa e solidária.

Os casos aqui relatados não foram isolados. Não bastava dar um fim à vida das mulheres militantes: as torturas, os estupros, as discriminações, as humilhações faziam parte das estratégias de Estado de aniquilação e extermínio dos grupos opositores à ditadura militar. Os agentes de Estado as vilipendiaram até a morte. Conspurcaram sua memória.

Há várias lacunas na nossa história. Uma delas é o vazio na vida social, política e afetiva do país devido à ignorância dos crimes de lesa-humanidade praticados em vários momentos da história e também pelos agentes da ditadura. Não há como revelar a verdade histórica sem recuperar a atuação das mulheres militantes.

Julio Fuchik, ${ }^{11}$ frente à morte imposta pelos nazistas que o sequestraram e o levaram aos fornos crematórios, fez um grande apelo para que não esqueçamos nem dos bons, nem dos maus. Por isso trouxemos aqui as denúncias feitas durante e depois do funcionamento da Comissão da Verdade, nas quais aparecem policiais mulheres que atuaram ativamente no centro da repressão política causando sequestros e mortes de militantes políticos. O nome delas deve fazer parte da lista dos torturadores responsáveis por assassinatos e desaparecimentos forçados.

Ao mesmo tempo, diante de tanta dor e sofrimento, deve-se a sobrevivência de muitas pessoas à solidariedade que se manifestou naqueles tempos difíceis - e nesse sentido as mulheres se destacaram. Foram muitas que anonimamente, em silêncio, nos garantiram a vida. Que a história também faça justiça a elas, que não podem ser esquecidas. 


\section{NOTAS}

1 Inês Etienne Romeu (1942-2015) foi militante da Vanguarda Popular Revolucionária (VPR), sequestrada pelo aparato repressivo da ditadura em 5 de maio de 1971. Aqui temos um trecho do relatório (p. 8) que ela entregou à OAB-RJ, em 5 de setembro de 1979, juntamente com outros documentos e informações sobre seu sequestro, as torturas sofridas e os nomes de outros militantes que foram mortos e que até hoje fazem parte da lista dos desaparecidos políticos. Ela deu também entrevista para o jornal $O$ Pasquim, que foi publicada na edição ${ }^{\circ}$ 607, de 12 a 18 de janeiro de 1981 , p. 4-5 e 26.

2 O "Esquadrão da Morte”, em São Paulo, foi criado nos finais de 1960 por Sérgio Paranhos Fleury, com a finalidade de exterminar "elementos considerados perigosos ou indesejáveis". Contou com o apoio oficial da Secretaria de Segurança Pública e do próprio governador do Estado, Abreu Sodré, que o declarou publicamente em programa de TV ("Pinga Fogo" na então TV Tupi). Disponível em: <sibila.com.br/cultura/o-esquadrao-da-morteno-rio-e-em-saopaulo/10643>. Acesso em: 9 jul. 2015.

3 DOI-Codi: Departamento de Operações e Informações - Centro de Operações de Defesa Interna. Órgão público, que contava com a participação das três forças armadas, da polícia federal, civil e militar sob o comando do Exército brasileiro com o objetivo de reprimir qualquer oposição à ditadura militar.

4 Depoimento dado por Arthur Scavone na $19^{\mathrm{a}}$ audiência pública da Comissão da Verdade do Estado de São Paulo "Rubens Paiva", no dia 12 de março de 2013, sobre os casos de Maria Augusta Thomaz e Márcio Beck Machado.

5123 - Arquivo Nacional, SNI:BR_DFAnBSB_V8_ASP_ACE_2726_80,PP.11-13.

6 Lourival Alves Pereira Gaeta (1927-1997), que também usava o codinome Mangabeira, era delegado de polícia do Dops (SP) e integrava a equipe de torturadores do DOI-Codi (SP). Era chefe de uma das equipes. Há diversas denúncias de torturas praticadas por ele. Uma delas sou eu quem faço: Lourival Gaeta, que usava o codinome de Mangabeira, foi o torturador que se masturbou enquanto eu estava amarrada à cadeira do dragão. Ao ejacular, jogou o sêmen em cima do meu corpo. Enquanto eu era torturada, Ustra entrava na sala e gritava: "Essa terrorista tem que falar!!”.

7 “Casa Azul” era o nome dado a uma base militar, localizada em Marabá (sul do Pará), que serviu para torturar e matar guerrilheiros da Guerrilha do Araguaia.

8 Citado em Actis (2006, p. 155).

9 “Cadeira do dragão" é um método de tortura que consiste numa cadeira recoberta com uma chapa metálica e braços de madeira. A pessoa é amarrada com fios elétricos desencapados pelo tronco, pelos tornozelos e pelos braços. São colocados também fios elétricos na vagina, no ânus e nos ouvidos. Um dos fios fica solto, e o torturador o coloca onde quiser, na boca, nos seios, no umbigo. Às vezes, ele joga um pouco de água para aumentar os choques. A pessoa leva choques por todo o corpo sem poder sequer se mexer, pois está toda amarrada.

10 A foto da tenente Neuza pode ser vista no caderno de imagens do livro de Godoy (2014).

11 Julio Fuchik (1903-1943) foi um dirigente comunista da antiga Tchecoslováquia. Durante os dias que antecederam sua morte, escreveu em pequenos pedaços de papel suas impressões e reflexões daquele momento. Depois de sua morte, seus escritos se transformaram no livro Testamento sob a forca.

\section{REFERÊNCIAS BIBLIOGRÁFICAS}

ACTIS, Munú et al. Ese infierno: conversaciones de cinco mujeres sobrevivientes de la ESMA. Buenos Aires: Altamira Memorias, 2006. 
ALVERGA, Alex Polari de. Inventário de cicatrizes. São Paulo: Comitê Brasileiro pela Anistia, 1978. AMERY, Jean de. En los límites de la mente: observaciones de un sobreviviente de Auschwitz y sus realidades. Apud "Ese Infierno", Buenos Aires: Editora Altamira, 2006

BRASIL. Comissão Nacional da Verdade (CNV). Relatório / Comissão Nacional da Verdade. Brasília: CNV, 2014a. v. I, t. I.

BRASIL. Comissão Nacional da Verdade (CNV). Relatório / Comissão Nacional da Verdade. Brasília: CNV, 2014b. v. III, t. 3.

CARNEIRO, Julia Dias. "Quantos morreram? Tantos quanto foram necessários”, diz coronel sobre ditadura. BBC Brasil, Rio de Janeiro, 26 mar. 2014. Disponível em: <http://www.bbc.com/portuguese/noticias/ 2014/03/140326_depoimento_coronel_ditadura_jc >. Acesso em: 11 jul. 2015.

COMISSÃO DE FAMILIARES DE MORTOS E DESAPARECIDOS POLÍTICOS. Dossiê Ditadura: mortos e desaparecidos políticos no Brasil. 1964-1985. São Paulo: Imprensa Oficial, 2009.

CRESCE o número de mulheres eleitas no Congresso, mas fatia ainda é só de 10\%. UOL, São Paulo, 6 out. 2014. Disponível em: <http://eleicoes.uol.com.br/2014/noticias/2014/10/06/cresce-numero-demulheres-eleitas-no-congresso-mas-fatia-ainda-e-de-so-10.htm>. Acesso em: 11 jul. 2015.

FACCHINI, Regina. Falsa ameaça. O Estado de S. Paulo, São Paulo, 19 jul. 2015. Caderno Aliás.

FARIA, Tales. Militantes de esquerda foram incinerados em usina de açúcar. Último Segundo, Brasília, 2 maio 2012. Disponível em: <http://ultimosegundo.ig.com.br/politica/2012-05-02/militantes-de-esquerdaforam-incinerados-em-usina-de-acucar.html>. Acesso em: 18 jul. 2015.

GIANORDOLI-NASCIMENTO, Ingrid Faria; TRINDADE, Zeidi Araújo; SANTOS, Maria de Fátima de Souza. Mulheres e militância: encontros e confrontos durante a ditadura militar. Belo Horizonte: Ed. UFMG, 2012.

GODOY, Marcelo. A Casa da Vovó: uma biografia do DOI-Codi (1969-1991), o centro de sequestro, tortura e morte da ditadura militar. São Paulo: Alameda, 2014.

GUERRA, Cláudio. Memórias de uma guerra suja. Rio de Janeiro: Topbooks, 2012.

NOSSA, Leonêncio. Mata: o major Curió e as guerrilhas no Araguaia. São Paulo: Companhia das Letras, 2012. SÃO PAULO (Estado). Comissão da Verdade do Estado de São Paulo "Rubens Paiva" (CEV-SP). Introdução. Disponível em: <http://verdadeaberta.org/relatorio/>. Acesso em: 15 nov. 2015.

TELES, Maria Amélia de Almeida. A verdade: o legado maior deixado por Inês Ettiene. Ponte, São Paulo, 28 abr. 2015. Disponível em: <http://ponte.org/a-verdade-o-legado-maior-deixado-por-ines-etienne/>. Acesso em: 11 jul. 2015.

Breve história do feminismo. São Paulo: Brasiliense, 1993.

Maria Amélia de Almeida Teles

\author{
São Paulo - SP - Brasil \\ amelinhateleslaglobo.com
}

Diretora da União de Mulheres de São Paulo. Integrante da Comissão da Verdade do Estado de São Paulo "Rubens Paiva". 
